Poster Section

\title{
Oral, topical, and inhalation of Calcarea carbonica derivative complex (M8) to treat inflammatory mammary carcinoma in dogs
}

\author{
Daniella Matos da Silva, Eneida Janiscki Da Lozzo, \\ Dorly de Freitas Buchi, Carolina Camargo de Oliveira, \\ Simone Domit Guérios
}

Federal University of Paraná, Brazil

\begin{abstract}
Background: Inflammatory mammary carcinoma (IMC) is locally aggressive, fast growing, highly malignant tumor that affects humans and dogs. Affected dogs usually are presented with generalized edema, pain, erythema, and skin ulceration in mammary glands. Surgery is not recommended and an effective treatment has not been established [1]. Calcarea carbonica derivative complex (M8) has demonstrated anticancer properties in a murine model, by improving innate immune response against tumor cells [2]. M8 is a complex high diluted medication comprised of Calcarea carbonica 16x, Aconitum napellus 20x, Arsenicum album 18x, Asa foetida 20x, Conium maculatum 17x, Ipecacuanha 13x, Phosphorus 20x, Rhus toxicodendron 17x, Silicea 20x, Sulphur 24x, and Thuya occidentalis 19x, dilution procedures have followed standard methodology described at the Brazilian Homeopathic Pharmacopoeia.
\end{abstract}

Aims: To describe different routes of M8 administration associated with oral pyroxican (non-steroidal antiinflammatory drug) to treat dogs with IMC.

Methodology: Three female dogs with 10 years old median age were presented to the Veterinary Teaching Hospital at Federal University of Parana, Curitiba (HV-UFPR) with cytological and clinical diagnosis of IMC. Patients were treated with oral $(0.5 \mathrm{~mL}, \mathrm{q} 12 \mathrm{~h})$, topical $(\mathrm{q} 12 \mathrm{~h})$ and inhalatory $(2 \mathrm{~mL}, \mathrm{q} 24 \mathrm{~h}$, through an ultrasonic inhalation device) M8, and oral pyroxican $(0.3 \mathrm{mg} / \mathrm{kg}, \mathrm{q} 24 \mathrm{~h})$. Thoracic radiographs showed pulmonary metastasis in all dogs.

Results: 7 days after initiating treatment all patients had clinical improvement. It was observed reduction on mammary glands inflammation and decreased pain sensitivity. One patient had 8 month of complete remission. The other two patients died 1 and 2 month after initial treatment. However none of the patients had pulmonary progressive disease, showed by radiographic examinations. Owners revealed treatment satisfaction in regards to quality of life improvement, easy M8 administration, good M8 palatability for dogs, and inflammation reduction.

Conclusion: The present report suggests that M8 influenced positively the anti -inflammatory treatment.

Keywords: Calcarea carbonica complex; inflammatory mammary carcinoma; routes of administration 


\section{References}

[1] Sorenmo K. Canine mammary gland tumors. Veterinary Clinics of North America: Small Animal Practice. 2003 33(3):573-96.

[2] Oliveira CC, Abud APR, Oliveira SM, Guimarães FSF, Andrade LF, Di Bernardi RP, Coletto ELO, Kuczera D, Da Lozzo EJ, Gonçalves JP, Trindade ES, Buchi DF. Developments on drug discovery and on new therapeutics: highly diluted tinctures act as biological response modifiers. BMC Complementary and Alternative Medicine 2011, 11(101): 2-11.

\section{(c)) EY-Nc-ND Licensed to GIRI}

Support: authors declare that this study received no funding

Conflict of interest: authors declare there is no conflict of interest

Received: 01 June 2012; Revised: 08 August 2012; Published: 30 September 2012.

Correspondence author: Simone Domit Guérios, sdguerios@ufpr.br

How to cite this article: da Silva DM, Da Lozzo EJ, Buchi DF, de Oliveira CC, Guérios SD. Oral, topical, and inhalation of Calcarea carbonica derivative complex (M8) to treat inflammatory mammary carcinoma in dogs. Int J High Dilution Res [online]. 2012 [cited YYYY Month dd]; 11(40):166-167. Proceedings of the XXVI GIRI Symposium; 2012 Sep 20-22;

Florence (Italy). GIRI; 2012; Available from: http://www.feg.unesp.br/ ojs/index.php/ijhdr/article/view/594/583 